Dept. of Animal Medicine (Infectious Diseases),

Fac. of Vet. Med., Kafr Elsheikh Univ., Kafr Elsheikh 33516, Egypt.

\title{
SEROLOGICAL SURVEY ON BLUETONGUE VIRUS INFECTION IN CAMELS AT TWO CAMEL-REARING REGIONS OF SOMALILAND
}

(With One Table and One Figure)

By

\section{Y.M. GHANEM; A.A. FAYED*; A.A. SAAD** and A.H. ABDELKADER***}

* Dept. of Internal Medicine and Infectious Diseases, Fac. of Vet. Med., Cairo University, Egypt.

** Dept. of Virology, Animal Health Research Institute, Dokki-Giza, Egypt. ***Laboratory of the Gulf Veterinary International Quarantine Management Company, Berbera, Somaliland, Somalia.

(Received at 1/10/2009)

\section{مسح سيرولوجى لعدوى فيروس اللسان الأزرق في مقاطعتان لتربية الابل في شمال الصومال}

\section{باسر محمد غانم ، عادل عبل العظبيم فابل ، اشرف احمد سعد

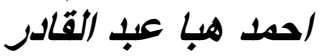

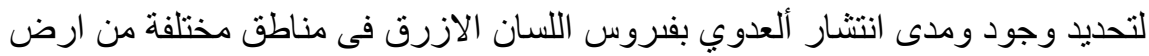

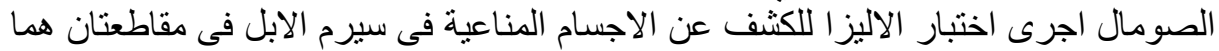

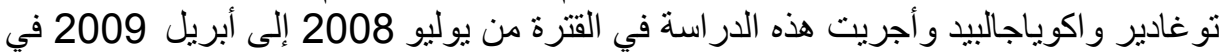



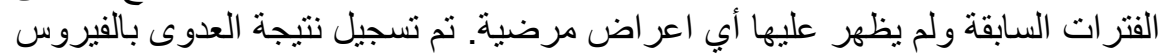

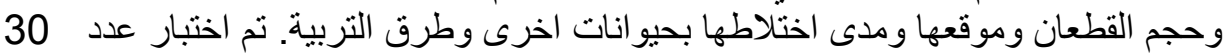

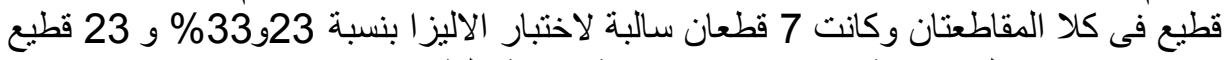

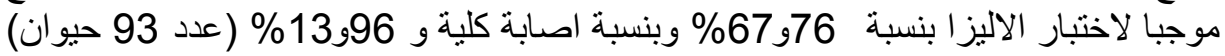

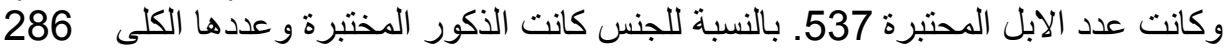

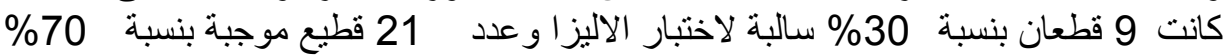

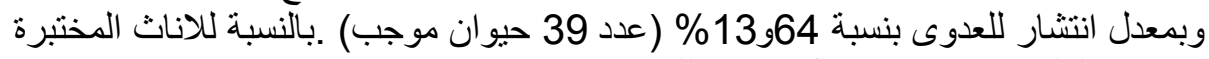

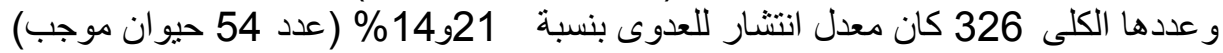

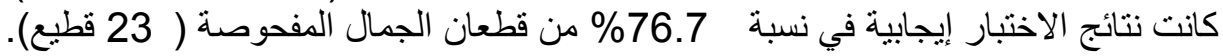

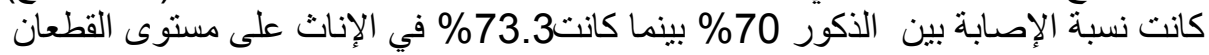

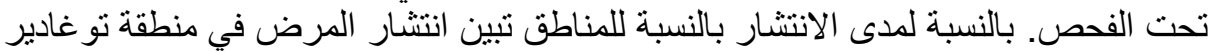

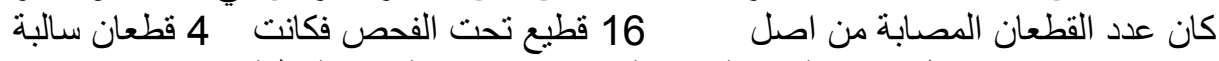

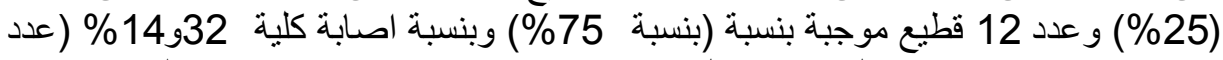
54 حيوان موجب) من اصل 377 جمل تحت الاختبار بينما كانت فى واجويا جالبيد كانت 


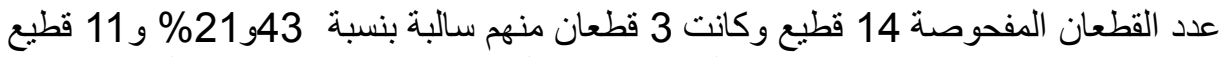



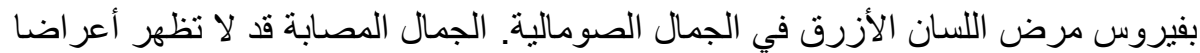

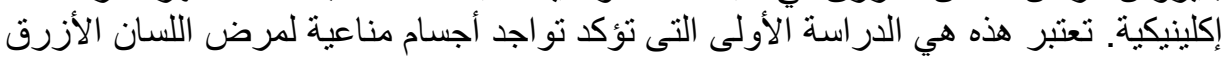
في الجمال في أرض الصئرمال بشمال الصومال.

\section{SUMMARY}

To determine the presence and prevalence of bluetongue virus infection in camels at different geographical regions of Somaliland, a competitive enzyme-linked immune-sorbent assay (cELISA) for the detection of serum antibody against BTV in clinically healthy camels has been carried out at northern Somalia in two main districts of camel-rearing regions namely, Togdheer, and Waqoyi Galbed in the period between July 2008 to April 2009. Results for bluetongue infection, herd size, and herd location, mixing with other animal species with various other associations were detected among demographic, husbandry and disease variables. All camels tested were apparently normal without showing clinical signs and without history of any specific clinical signs for BTV infection. Out of $30 \mathrm{camel} / \mathrm{herds}$ investigated, 7 (23.33\%) herds were serologically-negative and $23(76.67 \%)$ were serologically-positive by cELISA to BT virus infection with an overall prevalence of $13.96 \%$ $(\mathrm{n}=93)$. According to sex, for 286 males tested, 9 (30.0\%) herds were found serologically-negative and $21(70.0 \%)$ with an overall total prevalence of $13.64 \%(n=39)$. For 380 she camels tested, $54(14.21 \%)$ camels were serologically-positive and 326 (85.79\%) camels were serologically-negative. According to districts investigated, for Togdheer district, out of $16 \mathrm{camel} / \mathrm{herds}$ investigated, 4 (25.0\%) herds were serologically-negative and $12(75.0 \%)$ were found to be serologicallypositive by cELISA with overall prevalence of $14.32 \%(n=54)$ out of 377 tested camels. For Waqoyi Galbed district, Out of 14 camel/herds investigated, $3(21.43 \%)$ herds were serologically-negative and 11 (78.57\%) were serologically-positive by cELISA to BTV infection with a total prevalence of $12.33 \%(n=39)$ out of 289 camels tested. The results of the present investigation indicate that the bluetongue virus exists within the camel herds. The findings suggest that the disease is widely distributed in most investigated parts of the Somaliland where possible insect vectors may prevail and may suggest disease endimicity which is probably subclinical or in-apparent in camels of the Somaliland. The results presented here may consider the first confirmation of bluetongue virus antibody in camels in Somaliland.

Key words: Virology, blue tongue, camel, serology. 


\section{INTRODUCTION}

Bluetongue virus infects all species of domestic and wild ruminants (MacLachlan, 2004; and Stallnecht and Howerth, 2004) with similar pathogenesis and clinical signs which obviously lead to poor welfare in the animal population (Barret-Bayes and Maclachlan, 1995; MacLachlan, 2004; Verwoerd and Erasmus, 2004). However, Wernery and Kaaden (2002) encountered bluetongue virus infection in Camelids as a non pathogenic virus. BTV is the prototype member of the genus Orbivirus, family Reoviridae (Mertens et al., 2004). There are to date, 24 distinct serotypes of BTV have been described that all share common group antigens but distinguished on the basis of serotype-specific virus neutralization assays (Bonneau et al., 1999; Pritchard et al., 2004; Bréard et al., 2007b). BTV infection of ruminants occurs throughout much of the temperate and tropical regions of the world, coincident with the distribution of specific species of Culicoides biting midges that are biological vectors of the virus (Gibbs and Greiner 1994; Tabachnick 2004). The global distribution of BTV has historically been between latitudes of approximately $40-50{ }^{\circ} \mathrm{N}$ and $35^{\circ} \mathrm{S}$ but the virus recently (Since 1999) has spread northward in parts of the Mediterranean Basin and in North-Western Europe in 2006 (Hawkes 1995). BT occurs as a clinical disease of small ruminants in many countries of Africa, the Middle East, the Indian subcontinent, China, the United States, Mexico. BTV is also present in Southeast Asia, northern Australia, Papua New Guinea and northern South America, normally without associated clinical disease. Between 1998 and 2003, an unprecedented BT epidemic has occurred (Baylis 2002), affecting many countries in both the east and west Mediterranean areas.

Thirty-two species of Culicoides are considered to be involved in the transmission of BTV (Meiswinkel et al., 2004a). In Africa at least 10 species of Culicoides breed exclusively in the dung of indigenous herbivores (Meiswinkel et al., 2004b). Culicoides imicola appears to be the major vector of BTV in the Old World. The persistence between years should only be possible where adult Culicoides vectors are present year-round and are of sufficient abundance and competence to permit continual host-midge cycling of BTV over winter where overwintering of BTV was possible. (Mellor and Boorman 1995). However, no clinical signs or pathological lesions in camels caused by bluetongue virus have ever been reported, although some serologically-positive camels have been reported from a number of countries (Wernery and Kaaden 2002). Ruminants naturally infected with one serotype of BTV have a solid, 
lifelong immunity to the homologous serotype but only partial or no protection against other (heterologous) serotypes (Verwoerd and Erasmus 2004), thus recovered animals pose no threat for transmission of infection if they are confirmed to be virus-free prior to their movement. However, BTV infection of ruminants is prolonged but not persistent (MacLachlan 2004; Melville et al., 2004; White and Mecham 2004; Lunt et al., 2006). A true persistent BTV carrier state occurred in some animals (Barratt-Boyes and MacLachlan 1995; MacLachlan 2004; Lunt et al., 2006). The serotypes are differentiated by serum neutralisation tests, but there are cross-reactions between some serotypes. All BTV's share group antigens, which can be demonstrated by agar gel diffusion tests, fluorescent antibody tests and the group reactive ELISA. Prevalence of camel bluetongue in Somaliland has not been discussed. Therefore, the aim of the present study was to explore the serologic-prevalence and potential risk factors of camel BTV in the Somaliland using a commercially available competitive enzyme-linked immune-sorbent assay (C-ELISA).

\section{MATERIALS and METHODS}

\section{1- Study Area}

The present study was conducted during the period from July 2008 to April 2009 in the northern part of Somalia. Two main districts were covered in this study namely, Waqoyi Galbed, and Togdheer, which constitute (Figure1).

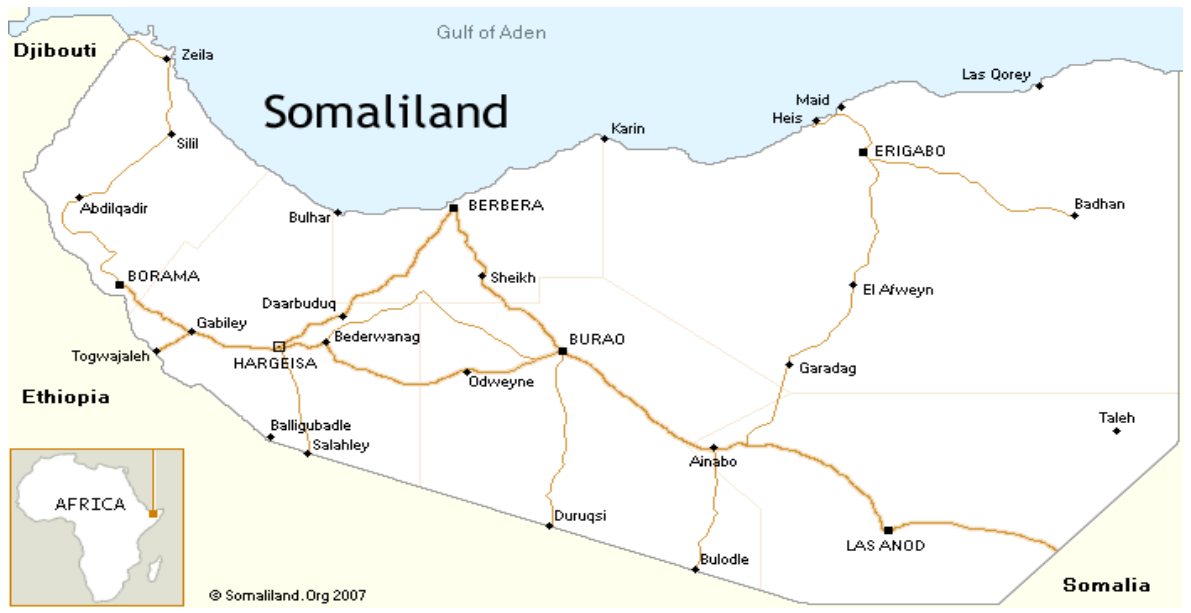

Fig. 1: A map of Somaliland showing locations of sample collection from camels for serosurvey of BTV

\section{2- Study Animals}


A total of 666 one humped unvaccinated camels blood sera were examined in this study and involved 30 herd/flocks (16, and 14 herds from Togdheer and Waqoyi Galbed respectively. The number of camel heads per herd/flock ranged from 14-31. Information of each camel sampled were obtained including, location, herd size, sex, age, health status, history of disease, whether reared individually, with other species or in a camel herd. Camel's sera were collected as 377 samples from Togdheer (162 males and 215 females) and 289 samples from Waqoyi Galbed (124 females and 165 females).

\section{3- Sample collecting}

A $10 \mathrm{ml}$ blood samples were collected and transferred to the laboratory of the Gulf International Veterinary Quarantine in Berbera city of Somaliland. The sera were separated and stored at $-20^{\circ} \mathrm{C}$ until testing

\section{4- Serological test}

Bluetongue virus antibody kit, cELISA Assay. Catalog No. 2875, 5. Product Code 5010.20- VMRD, Inc. P.O.Box 502 Pullman, WA, 99163; USDA Veterinary License No. 332, Serial No. P071008-004. solid plates 460. VMRD's competitive enzyme-linked immune-sorbent assay (cELISA) detects antibody to bluetongue virus in ruminant sera. It has been demonstrated to detect all 24 known serotypes of Bluetongue Virus (BTV). The serologic procedure of cELISA was carried-out according to the instruction of the enclosed pamphlet and the final plates was read on a plate reader (MR-96A Micro-plate Reader produced by Shenzhen mindary bio-medical electronics CO., LTD. Mindray Building, Keji $12^{\text {th }}$ Road South, High-Tech Industrial Park, Nanshan, ShenZhen518057, and P.R. China). Set the optical density (O.D.) reading wavelength to 620,630 or $650 \mathrm{~nm}$. Test Validation: The mean of the Negative Controls must produce an optical density greater than 0.300 and less than 2.000. The mean of the Positive Controls must produce an optical density less than or equal to $50 \%$ (one-half) of the mean of the Negative control. Test sera are positive if they produce an optical density less than $50 \%$ of the mean of the Negative Controls. Test sera that produce an optical density greater than or equal to $50 \%$ of the mean of the Negative Controls are negative.

\section{RESULTS}




\section{Overall Serologic prevalence of the two districts (Table 1)}

Out of investigated camel herds $(n=30), 23(76.7 \%)$ were found serologiclly positive to BTV infection and the remained herds $(7,23.3 \%)$ were negative. For 286 males included in the 30 herds, 9 (30\%) herds were found negative and $21(70 \%)$ were positive with a total district serologic prevalence of $13.64 \%(n=39)$. For 382 females included in the 30 herds, $8(26.7 \%)$ herds were serologic negative and $22(73.3 \%)$ herds were found positive with a total district serologic prevalence of $14.21 \%$ $(\mathrm{n}=54)$ (Table 1)

\section{For Togdheer (Table 1)}

Out of 16 camel herds investigated, 4 (25.0\%) herds were serologic-negative and $12(75.0 \%)$ were serologically positive by cELISA to Bluetongue virus infection. For 162 males included in the 16 herds, $5(31.25 \%)$ herds were found negative and $11(68.75 \%)$ were positive with a total prevalence of $13.58 \%(n=22)$. For 215 females included in the 16 herds, $4(25.0 \%)$ herds were serologic-negative and $12(75.0 \%)$ herds were found positive with a total prevalence of $14.88 \%$ $(n=32)$. All camels were apparently normal without showing clinical signs and without history of a specific clinical signs for BT vial infection.

\section{For Waqoyi Galbed (Table 1)}

Out of 14 camel herds investigated, $3(21.43 \%)$ herds were serologic-negative and $11(78.57 \%)$ were serologically positive by cELISA to Bluetongue virus infection with a total prevalence of $12.33 \%$ $(n=39)$. For 124 males included in the 14 herds, $4(28.57 \%)$ herds were negative and $10(71.4 \%)$ were positive with a total prevalence of $13.71 \%$ $(\mathrm{n}=17)$. For 165 females included in the 14 herds, $4(28.6 \%)$ herds were negative and $10(71.4 \%)$ herds were positive with with a total prevalence of $13.33 \%(n=22)$. All camels were apparently normal without showing clinical signs and without history of any specific clinical signs for BT viral infection. 
Table 1: Serological survey results on district and herd levels at Somaliland by cELISA.

\begin{tabular}{|c|c|c|c|c|c|c|c|c|c|c|c|c|c|c|c|c|}
\hline District & $\begin{array}{c}\text { Herd } \\
\text { No. }\end{array}$ & $\begin{array}{c}\text { Herd } \\
\text { size }\end{array}$ & $\begin{array}{l}\text { Male } \\
\text { Camels }\end{array}$ & & & & & $\begin{array}{l}\text { Female } \\
\text { Camels }\end{array}$ & & & & & & Total & & \begin{tabular}{|l|} 
Contact \\
with other \\
species
\end{tabular} \\
\hline & & & cELISA & & & & & cELISA & & & & & & & & \\
\hline \multirow[t]{17}{*}{ Togdheer } & & & $\begin{array}{l}\text { Total } \\
\text { Males }\end{array}$ & $+\mathrm{ve}$ & $\%$ & -ve & $\%$ & \begin{tabular}{|l} 
Total \\
Females
\end{tabular} & $+\mathrm{ve}$ & $\%$ & & $\%$ & & ve $\%$ & -ve $\%$ & \\
\hline & 1 & 22 & 10 & 1 & 10.0 & 9 & 90.0 & 12 & 1 & 8.33 & & 91.67 & 2 & 9.09 & $\begin{array}{ll}20 & 90.91\end{array}$ & Cattle \\
\hline & 2 & 26 & 10 & 0 & 0.0 & 10 & 100.0 & 16 & 0 & 0.0 & & 100.0 & 0 & 0.0 & $\begin{array}{ll}26 & 100.0\end{array}$ & Sheep, goats \\
\hline & 3 & 25 & 11 & 4 & 36.36 & 7 & 63.64 & 14 & 3 & 1.43 & 1 & 78.57 & & 28.0 & $\begin{array}{ll}18 & 72.0\end{array}$ & \begin{tabular}{|l|} 
Cattle, \\
sheep, goats
\end{tabular} \\
\hline & 4 & 30 & 16 & 1 & 6.25 & 15 & 93.75 & 14 & 2 & 14.29 & & 85.71 & 3 & 10.0 & $27 \quad 90.0$ & None \\
\hline & 5 & 22 & 9 & 3 & 33.33 & 6 & 66.67 & 13 & 4 & 30.77 & 9 & 69.23 & & 31.82 & $\begin{array}{ll}15 \quad 68.18 \\
\end{array}$ & Cattle \\
\hline & 6 & 17 & 8 & 0 & 0.0 & 8 & 100.0 & 9 & 1 & 11.11 & 8 & 88.89 & & 5.88 & 1694.12 & None \\
\hline & 7 & 25 & 12 & 2 & 16.67 & 10 & 83.33 & 13 & 4 & 30.77 & 9 & 69.23 & & 24.0 & 1976.0 & Cattle \\
\hline & 8 & 28 & 12 & 0 & 0.0 & 12 & 100.0 & 16 & 0 & 0.0 & 16 & 100.0 & 0 & 0.0 & $28 \quad 100.0$ & None \\
\hline & 9 & 21 & 9 & 2 & 22.22 & 7 & 77.78 & 12 & 3 & 25.0 & 9 & 75.0 & 5 & 23.81 & $\begin{array}{ll}16 & 76.19\end{array}$ & Sheep, goats \\
\hline & 10 & 20 & 7 & 3 & 42.86 & 4 & 57.14 & 13 & 4 & 30.77 & 9 & 69.23 & 7 & 35.0 & $13 \quad 65.0$ & \begin{tabular}{|l|} 
Cattle, \\
sheep, goats
\end{tabular} \\
\hline & 11 & 25 & 10 & 1 & 10.0 & 9 & 90.0 & 15 & 3 & 20.0 & & 80.0 & 4 & 16.0 & 2184.0 & None \\
\hline & 12 & 31 & 13 & 0 & 0.0 & 13 & 100.0 & 18 & 0 & 0.0 & & 100.0 & 0 & 0.0 & $31 \quad 100.0$ & None \\
\hline & 13 & 26 & 12 & 1 & 8.33 & 11 & 91.67 & 14 & 2 & 14.29 & & 85.71 & 3 & 11.54 & $23 \quad 88.46$ & None \\
\hline & 14 & 18 & 8 & 2 & 25.0 & 6 & 75.0 & 10 & 3 & 30.0 & 7 & 70.0 & 5 & 27.78 & $13 \quad 72.22$ & Cattle \\
\hline & 15 & 21 & 8 & 0 & 0.0 & 8 & 100.0 & 13 & 0 & 0.0 & & 100.0 & 0 & 0.0 & $\begin{array}{ll}21 & 100.0\end{array}$ & None \\
\hline & 16 & 20 & 7 & 2 & 28.57 & 5 & 71.43 & 13 & 2 & 15.38 & & 84.62 & & 20.0 & 1680.0 & Cattle \\
\hline Total & & $\begin{array}{c}37 \\
7 \\
\end{array}$ & 162 & 22 & 13.58 & 140 & 86.42 & 215 & 32 & 14.88 & & 85.12 & & 14.32 & $323 \quad 85.68$ & \\
\hline \multirow[t]{14}{*}{$\begin{array}{l}\text { Waqoyi } \\
\text { Galbed }\end{array}$} & 1 & 23 & 10 & 1 & 10.0 & 9 & 90.0 & 13 & 2 & 15.38 & & 84.62 & 3 & 13.04 & $20 \quad 86.96$ & sheep, goats \\
\hline & 2 & 21 & 9 & 2 & 22.22 & 7 & 77.87 & 12 & 3 & 25.0 & 9 & 75.0 & 5 & 23.81 & $\begin{array}{ll}16 & 76.19\end{array}$ & $\begin{array}{l}\text { cattle, } \\
\text { sheep, goats }\end{array}$ \\
\hline & 3 & 23 & 9 & 0 & 0.0 & 9 & 100.0 & 14 & 0 & 0.0 & 1 & 100.0 & 0 & 0.0 & $23 \quad 100.0$ & None \\
\hline & 4 & 20 & 8 & 1 & 12.50 & 7 & 87.50 & 12 & 2 & 16.67 & & 83.33 & 3 & 15.0 & 1785.0 & sheep, goats \\
\hline & 5 & 24 & 9 & 2 & 22.22 & 9 & 77.87 & 15 & 3 & 20.0 & & 80.0 & 5 & 19.23 & $\begin{array}{ll}21 & 80.77\end{array}$ & $\begin{array}{l}\text { cattle, } \\
\text { sheep, goats }\end{array}$ \\
\hline & 6 & 18 & 8 & 0 & 0.0 & 8 & 100.0 & 10 & 0 & 0.0 & & 100.0 & 0 & 0.0 & $\begin{array}{ll}18 & 100.0\end{array}$ & None \\
\hline & 7 & 17 & 7 & 2 & 28.57 & 5 & 71.43 & 10 & 2 & 20.0 & 8 & 80.0 & 4 & 23.53 & $\begin{array}{ll}13 & 76.47 \\
\end{array}$ & sheep, goats \\
\hline & 8 & 14 & 6 & 1 & 16.67 & 5 & 83.33 & 8 & 1 & 12.50 & 7 & 87.50 & 2 & 14.29 & $\begin{array}{ll}12 & 85.71 \\
\end{array}$ & None \\
\hline & 9 & 23 & 11 & 2 & 18.18 & 9 & 81.82 & 12 & 3 & 25.0 & 9 & 75.0 & 5 & 21.74 & $\begin{array}{ll}18 & 78.26 \\
\end{array}$ & sheep, goats \\
\hline & 10 & 22 & 9 & 0 & 0.0 & 9 & 100.0 & 13 & 2 & 15.38 & 1 & 84.62 & 2 & 9.09 & $20 \quad 90.91$ & None \\
\hline & 11 & 23 & 11 & 0 & 0.0 & 11 & 100.0 & 12 & 0 & 0.0 & 12 & 100.0 & 0 & 0.0 & $23 \quad 100.0$ & None \\
\hline & 12 & 19 & 8 & 1 & 12.50 & 7 & 87.50 & 11 & 1 & 9.09 & 10 & 90.91 & 2 & 10.53 & $17 \quad 89.47$ & None \\
\hline & 13 & 17 & 8 & 2 & 25.0 & 6 & 75.0 & 9 & 0 & 0.0 & 9 & 100.0 & 2 & 28.57 & $\begin{array}{ll}15 & 71.43\end{array}$ & None \\
\hline & 14 & 25 & 11 & 3 & 27.27 & 8 & 72.73 & 14 & 3 & 21.43 & 1 & 87.57 & 6 & 24.0 & $\begin{array}{ll}19 & 76.0\end{array}$ & $\begin{array}{l}\text { cattle, } \\
\text { sheep, goats }\end{array}$ \\
\hline Total & & 289 & 124 & 17 & 13.71 & 107 & 86.29 & 165 & 22 & 13.33 & & 86.67 & & 12.33 & $250 \quad 87.67$ & \\
\hline
\end{tabular}




\section{DISCUSSION}

Somaliland had never previously recorded the presence of BTV in camels and the present study revealed an overall serologic-prevalence of $13.96 \%$. The differences observed between geographic areas are not significant as in Togdheer it was $14.32 \%$ while in Waqoyi Galbed was $12.33 \%$ (Table 1). The presence of BTV antibodies in these sera had previously been demonstrated by the c-ELISA. In endemic areas, serologic-prevalence's of 46-52\% in sheep, $44 \%$ in goats and 33-95\% in cattle have been reported (Formenty et al., 1994; Thevasagayam et al., 1996). Our findings of $12.33 \%-14.32 \%$ serologic-prevalence are relatively low, however, they suggest that BTV is widespread and endemic in the country. This result may the first confirmation of BTV antibody in camels from Somaliland. Our interviews with farmers and officials highlighted the fact that vaccination against BTV diseases as a major economic and public health importance is not performed in Somaliland. Epidemic disease may constitute a serious problem for Somaliland's rural economy in future, and the situation is likely to worsen in the next few years. The overall prevalence of the BTV antibodies in camels in the two districts was $12.33 \%-14.32 \%$, and serologic-positive animals were detected in both districts sampled. Failure to detect serologic-reactors in these serologic-negative herds may due to the relatively low number of animals screened. In addition, mild disease may go unnoticed and/or unreported. This may be attributed to the nearness of these districts to the states of Awdal, where BTV is considered endemic in Ethiopia as a border country, and to the unrestricted movement of relatively large numbers of camels, cattle, sheep and goats from these 'endemic' regions into the Somaliland districts. One of the factors that might contribute to these higher levels in tested herd camels. The cELISA described here detected positive BTV antibody in sera from camels in the two studied districts comprising 30 herds. This assay has proved reliable for the detection of BTV antibody at the farm level and could be used with confidence. Smriti and Shringi (2005), found that cELISA being highly sensitive and specific followed by CCIE and AGID test. BT, it is essential to develop methods for accurate prediction of BT risk in space and time. Persistence of BTV within a particular geographical area does not mean "static". Once a vertebrate host is infected with BTV it either dies or mounts an enduring antibody response and so becomes resistant to further infection. This means that within any small geographical area (a farm or village) most 
or all of the initially susceptible hosts are likely to be infected and thus become "unavailable" to the virus within a fairly short space of time. BTV can only survive under such constraints by continually moving to new locations occupied by naïve vertebrate hosts. These movements are via the agency of viraemic hosts or infected vectors. BTV is therefore a peripatetic virus and even within its enzootic zones its activity may be envisaged as a pattern of endlessly shifting viral "hot spots". Where annual bouts of BT occur, they may represent new introductions (from adjacent infected areas) or may be the visible evidence of low-level persistence from year to year. However, neither clinical signs nor gross pathological alterations caused by Bluetongue virus in all species of camelids (Wernery and Kaaden, 2002) with exception in only one llama was found with signs with respiratory manifestation in association with abortion (Fowlar, 1998). Based on our results a further studies on prevalence of BTV should carried-out to avoid the epidemic for this disease in Somaliland. Serotyping of the existence and persistence of BTV in Somaliland's camels is extremely urgent . Moreover, epidemiological studies need be done to explore the current status of the disease in other ruminants and other animals to enable the public veterinary authorities to construct concrete program for prevention of the disease within animal herds in Somaliland or transmission of the disease via animal trading to the other countries.

\section{REFERENCES}

Barratt-Boyes, S.M. and MacLachlan, N.J. (1995): Pathogenesis of bluetongue virus infection of cattle. Journal of the American Veterinary Medical Association. 206, 1322-1329.

Baylis, M. (2002): The re-emergence of bluetongue. The Veterinary Journal. 164: 5-6.

Bonneau, K.R.; Zhang, N.; Zhu, J.; Zhang, F.; Li, Z.; Zhang, K.; Xiao, L.; Xing, W. and MacLachlan, N.J. (1999): Sequence comparison of the L2 and S10 genes of bluetongue viruses from the United States and the People's Republic of China. Virus Research. 61: 153-160.

Bréard, E.; Sailleau, C.; Nomikou, K.; Hamblin, C.; Mertens, P.; Mellor, P.S.; El Harrack, M. and Zientara, S. (2007b): Molecular epidemiology of serotype 4 bluetongue viruses isolated in the Mediterranean Basin between 1979 and 2004. Virus Research. 125: 191-197. 
Formenty, P.; Domenech, J.; L'Auginie, F.; Ouattara, M.; Diawara, S.; Raath, J.P.; Grobler, D.; Leforban, Y. and Angba, A. (1994): Epidemiologic survey of bluetongue virus in sheep, cattle and various species of wildlife in Cote d'Ivoire. Revue Scientifique et Technique de l'Office International des Epizooties. 13: 737-751.

Fowler, M.E. (1998): Medicine and Surgery of South American Camelids. Iowa State University Press, Ames-Cited by Wernery and Kaaden (2002).

Gibbs, E.P. and Greiner, E.C. (1994): The epidemiology of bluetongue. Comparative Immunology, Microbiology and Infectious Diseases. 17: 197-206.

Hawkes, A. (1995): The Global Distribution of Bluetongue. Bluetongue Disease in Southeast Asia and the Pacific. Proceedings of the First Southeast Asia and the Pacific Regional Bluetongue Symposium, Kunming, China, 22 -24 August 1995. Australian Centre for International Agricultural Research Proceedings 66. ACIAR proceedings. 66: 6-14.

Lunt, R.A.; Melville, L.; Hunt, N.; Davis, S.; Rootes, C.L.; Newberry, K.M.; Pritchard, L.I.; Middleton, D.; Bingham, J.; Daniels, P.W. and Eaton, B.T. (2006): Cultured skin fibroblast cells derived from bluetongue virus inoculated sheep and fieldinfected cattle are not a source of late and protracted recoverable virus. The Journal of General Virology. 87: 3661-3666.

MacLachlan, N.J. (2004): Bluetongue: pathogenesis and duration of viraemia. Veterinaria Italiana. 40: 462-467.

Meiswinkel, R.; Gomulski, L.M.; Delécolle, J.-C.; Goffredo, M. and Gasperi, G. (2004a): The taxonomy of Culicoides vector Complexes - unfinished business. Veterinaria. Italiana. 40: 151-159.

Meiswinkel, R.; Venter, G.J. and Nevill, E.M. (2004b): Vectors: Culicoides spp. In Infectious Diseases of Livestock, 2nd ed, pp 93-136. Edited by J. A. W. Coetzer and R. Tustin. Oxford University Press, Cape Town.

Mellor, P.S. and Boorman, J. (1995): The transmission and geographical spread of African horse sickness and bluetongue viruses. Annals of Tropical Medicine and Parasitology. 89: 1-15. 
Melville, L.F.; Hunt, N.T.; Davis, S.S. and Weir, R.P. (2004): Bluetongue virus does not persist in naturally infected cattle. Veterinaria Italiana. 40: 502-507.

Mertens, P.P.; Diprose, J.; Maan, S.; Singh, K.P.; Attoui, H. and Samuel, A.R. (2004): Bluetongue virus replication, molecular and structural biology. Veterinaria Italiana. 40: 426-437.

Pritchard, L.I.; Sendow, I.; Lunt, R.; Hassan, S.H.; Kattenbelt, J.; Gould, A.R.; Daniels, P.W. and Eaton, B.T. (2004): Genetic diversity of bluetongue viruses in south East Asia. Virus Research. 101: 193-201.

Smriti, S. and Shringi, B.N. (2005): Comparative efficacy of standard AGID, CCIE and competitive ELISA for detecting bluetongue virus antibodies in indigenous breeds of sheep and goats in Rajasthan, India. Journal of Veterinary Science. Korean Society of Veterinary Science, Daejon, Korea Republic. 6 (1): 77-79.

Stallnecht, D.E. and Howerth, E.W. (2004): Epidemiology of bluetongue and epizootic disease in wildlife: surveillance methods. Veterinaria Italiana. 40: 203-207.

Tabachnick, W.J. (2004): Culicoides and the global epidemiology of bluetongue virus infection. Veterinaria Italiana. 40: 145-150.

Taylor, W.P. (1986): The epidemiology of bluetongue. Revue Scientifique et Technique de l'Office International des Epizooties. 5 (2): 351-356.

Thevasagayam, J.A.; Wellby, M.P.; Mertens, P.P.C.; Burroughs, J.N. and Anderson, J. (1996): Monoclonal antibody based competitive ELISA for the detection of antibodies against epizootic haemorrhagic disease of deer virus. J. Virol. Methods. 57: 117-126.

Verwoerd, D. and Erasmus, B.J. (2004): Bluetongue. In: Coetzer J.A., Tustin R.C. (Eds). Infectious Diseases of Livestock, 2nd ed. Oxford University Press, Cape Town, pp 1201-1220.8

Wernery, U. and Kaaden, O.R. (2002): Infectious Diseases of Camelids. Blackwell Science, Berlin, pages 23, 33, 87, 137, 181, 276, 285, 373.

White, D.M. and Mecham, J.O. (2004): Lack of detectable bluetongue virus in skin of seropositive cattle: implications for vertebrate overwintering of bluetongue virus. Veterinaria Italiana. 40: 513-519. 